Revue de sciences sociales sur les arts, la culture et les idées

$2 \mid 2018$

Arpenter la vie littéraire

\title{
Creating La Vie littéraire au Québec in the Digital Era
}

La vie littéraire au Québec 2.0. Croissance, seuils et réduction

La vida literaria en Quebec 2.0 : crecimiento, umbrales y reducción

Marie-Frédérique Desbiens and Chantal Savoie

Translator. Jean-Yves Bart

(2) OpenEdition

Journals

Electronic version

URL: http://journals.openedition.org/bssg/218

DOI: $10.4000 /$ bssg. 218

ISSN: 2490-9424

Publisher

Presses universitaires de Vincennes

Electronic reference

Marie-Frédérique Desbiens and Chantal Savoie, "Creating La Vie littéraire au Québec in the Digital Era", Biens Symboliques / Symbolic Goods [Online], 2 | 2018, Online since 12 April 2018, connection on 04 March 2021. URL: http://journals.openedition.org/bssg/218 ; DOI: https://doi.org/10.4000/bssg.218 
La vie littéraire au Québec 2.0

Croissance, seuils et réduction
Creating La Vie littéraire au Québec in the Digital Era

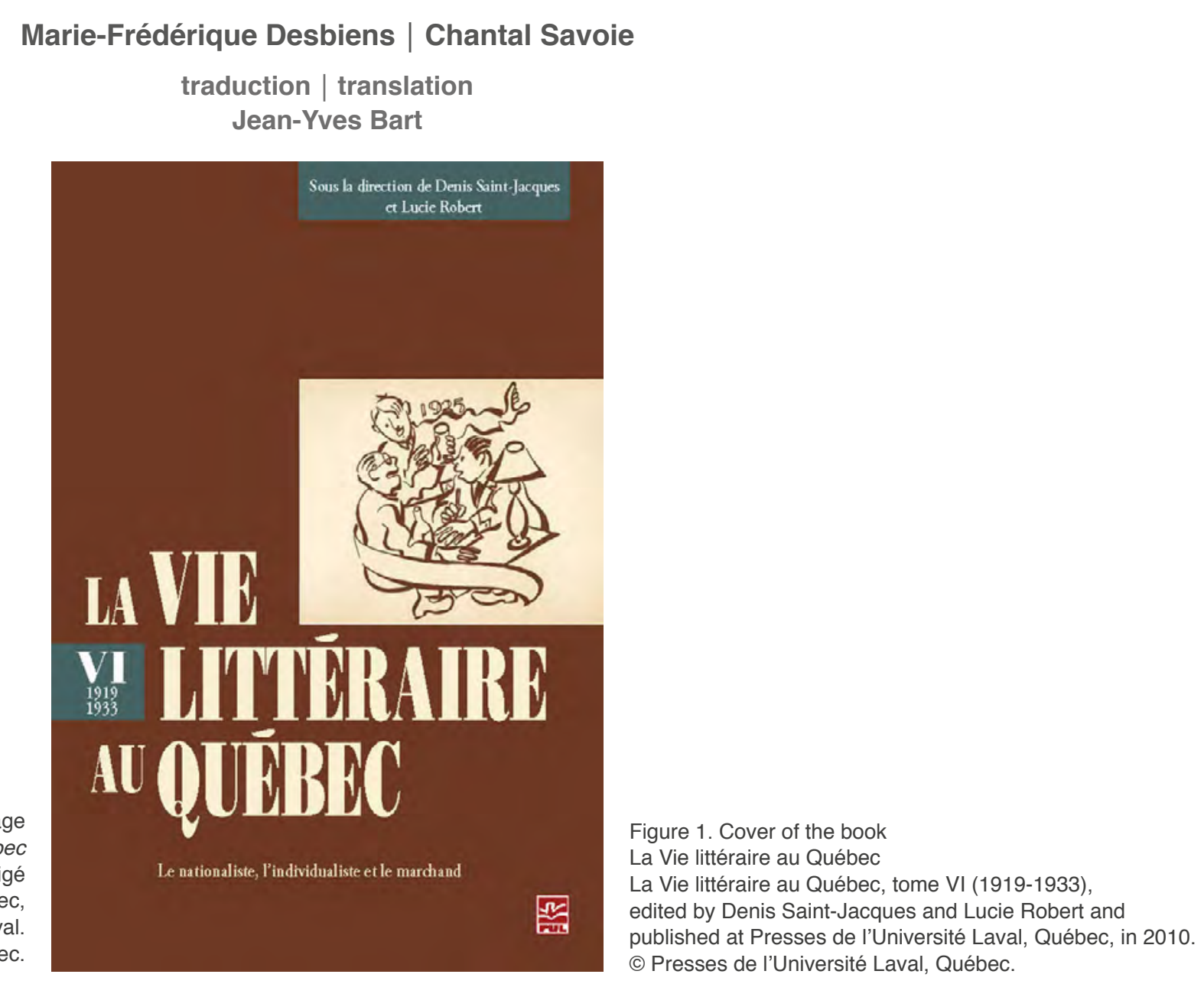




\section{Introduction}

Nous arrimant au volet de la problématique de ce numéro qui s'intéresse aux usages des bases de données, aux "coulisses " de leur conception et de leur utilisation - depuis les objectifs qui en orientent la genèse jusqu'à la vision de l'histoire littéraire qui les sous-tend, en passant par les problèmes méthodologiques qu'elles posent -, nous souhaitons dans cet article expliciter les modalités du tournant numérique, amorcé il y a cinq ans par l'équipe de "La vie littéraire au Québec » (VLQ - signalons que les premiers tomes sont téléchargeables gratuitement en PDF, comme celui-ci sur la période 1764-1805). Ce virage est venu consolider une modernisation des outils et du fonctionnement de l'équipe, modernisation dont la portée se voit décuplée par le volume de textes et d'interactions inédits qu'impliquent les périodes historiques qui nous occupent actuellement, soit les années 1934 à 1962. Le contexte d'une équipe et d'une méthode très stables depuis plus de 25 ans offre à cet égard une occasion privilégiée de prolonger l'exercice autoréflexif initié dans le cadre de ce virage numérique et de tenter de départager ce qui, au sein de ce processus, tiendrait plus proprement d'une « révolution » numérique et ce qui relèverait plutôt d'un impact à moyen terme de la rupture introduite par l'École des Annales et de ses effets sur l'histoire littéraire, lesquels se répercutent sur l'utilisation des bases de données.

\section{Retour sur le projet, ses objectifs et ses méthodes}

Depuis son premier tome paru en 1992, La Vie littéraire au Québec vise la constitution d'une grande histoire littéraire du Québec (de 1764 au seuil des années 1960), par l'examen des textes conjoint à celui du contexte. L'entreprise se démarque des synthèses antérieures en ce qu'elle ne cherche pas à consacrer

\section{Introduction}

This paper partakes in this dossier's examination of databases: their users and the behind-the-scenes work involved in their design and use - from the objectives at their inception to their underlying vision of literary history and the methodological issues they raise. To do so, it explores the modalities of the digitalization undertaken five years ago by the team of La Vie littéraire au Québec (VLQ - it should be noted that the first volumes of the series are available for free downloading, like the first one, for instance, which studies the period 1764-1805). This transition was part of the modernization of the team's tools and working methods -the scope of this modernization being actually considerably broadened by the increased volume of texts and interactions involved in the historical period we have been working on recently (1934-1962). As both our team and method have remained very stable for more than twenty-five years, we have a valuable opportunity to expand on the self-examination inspired by digitalization, and to attempt to separate what in this process reflects a genuine digital "revolution" from the outcomes of a medium-term impact of the shift introduced by the Annales School in the field of literary history, which in turn informed the use of databases.

\section{The Project, its Objectives and Methods}

Since the publication of its first volume in 1992, La Vie litteraire au Québec has been working towards retracing a large-scale literary history of Quebec (from 1764 to the early 1960s) by examining texts in context. This undertaking differs from previous syntheses in that it is not aimed at consecrating oeuvres and reputations, but 
des œuvres et des réputations, mais plutôt à prendre en compte l'ensemble du champ et de l'activité littéraires, par les processus de production, de circulation, de diffusion et de réception de la littérature. Notre approche globale relève ainsi de la sociologie de la littérature issue des travaux de Pierre Bourdieu (1992), Jacques Dubois (1978), Michel Van Schendel (1979) et al., centrée sur le système général d'agents, d'instances et de codes, et pense la littérature comme une formation discursive spécifique (Foucault 1969), centrale dans la constitution d'un espace public (Habermas 1962). Nos ancrages théoriques ont progressivement intégré l'apport de la sociologie des réseaux (Denis \& Marneffe [de] 2006 ; Lacroix 2014) et de l'histoire littéraire de la presse (Kalifa, Régnier, Thérenty, Vaillant 2012 ; Thérenty 2007). Les recherches contemporaines en études féministes, en études théâtrales et en musicologie (chanson) informent par ailleurs constamment nos réflexions, révélant l'interdépendance des différents secteurs d'activité culturelle et la dimension foncièrement interdisciplinaire de ces pratiques. Ce cadre théorique, articulé à une dimension herméneutique déployée dans la relecture des textes, nous permet de penser non seulement la littérature, mais surtout la vie littéraire, en ce qu'elle vise à « rendre compte d'un objet mouvant plutôt que d'un objet clos et [à] l'aborder d'un œil attentif aux transformations, aux changements, à ce qui bouge par opposition à ce qui serait immobile. Mouvant parce que vivant, donc, et saisi dans son présent, in vivo et in situ » (Robert 2012 : 95)

Les bases théoriques du projet ont été constantes au fil des ans, et il y aurait peu à en dire du strict point de vue d'une " évolution " méthodologique. Quant à l'évolution des enjeux soit formels, soit institutionnels, ce sont eux qui, déjà, ont orienté la trame narrative principale des six tomes parus, retraçant l'histoire du processus par lequel la littérature québécoise acquiert progressivement sa légitimité et son autonomie relative, pour reprendre la terminologie rather at embracing the literary field and literary activity in their full breadth, by looking at the production, circulation, diffusion, and reception of literature. Our overall approach draws on the sociology of literature that came out of the work of Pierre Bourdieu (1996), Jacques Dubois (1978), and Michel Van Schendel (1979) et al., and that is focused on the general system of agents, bodies, and codes, within a perception of literature as a distinctive discursive formation (Foucault 2002) which is key to the making of a public space (Habermas 1962). Our theoretical framework has progressively expanded to include insights from the sociology of networks (Denis \& Marneffe [de] 2006; Lacroix 2014) and the literary history of newspapers (Kalifa, Régnier, Thérenty, Vaillant 2012; Thérenty 2007). Contemporary research in feminist studies, theatre studies, and musicology (chanson) also constantly informs our research by revealing both the interdependence of various cultural activity sectors and the fundamentally interdisciplinary quality of these practices. Together with a hermeneutic approach to our review of the texts, this theoretical framework helps us to consider not only literature, but above all literary life in that it aims to 'account for a moving object rather than a closed object, and to approach it while paying attention to transformations, changes, and to what moves as opposed to what stays motionless. It is moving because it is alive, and seized in its present, in vivo and in situ (Robert 2012: 95).

The project's theoretical bases have remained constant over the years: there would therefore be little to say about them in terms of a strict methodological "evolution." Formal and institutional stakes have oriented the main narrative spine of the six volumes published so far, which retrace how the literature of Quebec gradually gained its legitimity and relative autonomy, to use Bourdieu's terminology. However, the quantitative and material dimension of our project 
de Bourdieu. Toutefois, la dimension quantitative et matérielle de notre projet a moins souvent été évoquée, alors que le travail que nous réalisons sur ces plans a lui aussi une histoire. C'est cette histoire matérielle qui nous servira de fil directeur pour présenter nos bases de données et montrer qu'elles permettent non seulement l'adaptation de nos outils et perspectives à l'ère numérique, mais qu'elles représentent aussi une occasion de faire un pas de plus dans la direction d'une histoire littéraire qui intégrerait pleinement sa dimension quantitative, proche en cela du souhait exprimé par

Franco Moretti (2008).

La confrontation au quantitatif n'étant pas nouvelle et la vie des chercheurs qui nous ont précédées n'ayant été ni plus simple ni plus compliquée à cet égard, mentionnons que la nature même du projet intellectuel qui est à la base de la série d'ouvrage La Vie littéraire au Québec a de tout temps impliqué des méthodes de collecte, d'indexation et de cadrage des données explicites et explicitées ${ }^{1}$. Ces opérations, qui nécessitent de constants allersretours entre totalité et sélection, entre le foisonnement de plus en plus vertigineux des sources et une synthèse toujours aussi strictement cadrée, évoluent, certes, et c'est le plus souvent sous l'angle de leur transformation qu'on les aborde, en focalisant sur ce qui change, s'amplifie et se déploie. Nous aimerions ici faire porter notre regard sur le rôle de régulation, l'effet stabilisateur du

1 Rappelons l'empan couvert : le premier tome de notre série, qui porte sur les années 1764-1805, permettait d'aspirer à une certaine exhaustivité, en traitant de tous les auteurs (connus ou retrouvés au moment des recherches) et de tous les textes (connus ou retrouvés au moment des recherches). A l'autre bout du spectre, les tomes 7 et 8 en préparation (qui couvrent les années 1934-1947, puis 1948-1962) ont sans surprise entraîné leur lot de défis en regard de la gestion documentaire et du traitement sensible qu'il est possible d'en faire, tant du point de vue du personnel littéraire, du marché et de la publication que de la réception des œuvres. has been less often discussed, even though our work in these areas also has a history of its own. This material history will be the main guiding thread in this presentation of our databases, showing that in addition to accommodating the adaptation of our tools and approaches to the digital era, they also offer the opportunity to make an additional step towards a literary history with a genuinely integrated quantitative component, reflecting the wishes formulated by Franco Moretti (2005).

Dealing with quantitative data is not something new, and the task of the researchers before us was no more simple or complex in that regard. Due to the very nature of the intellectual project at the heart of the La Vie litterraire au Québec book series, explicit and explicated methods for collecting, indexing and framing data have always been necessary to the process of compiling these volumes. ${ }^{1}$ Requiring a constant back-and-forth between the whole and parts, between an increasingly dazzling abundance of sources and the expected synthesis which is always very strictly framed, these quantitative processings have admittedly changed, and they are most often addressed in terms of their transformation, with a focus on what has been transformed, amplified, or deployed. Here we will emphasize the regulatory role, the stabilizing effect

1 It is worth recalling the timespan covered by these books: when we compiled the first volume in our series for the 1764-1805 period, it was possible to be fairly exhaustive by covering all authors and all texts (known or found at the time of our research). At the other end of the spectrum, volumes 7 and 8, currently in production, which cover the years 1934-1947 and 1948-1962 have unsurprisingly raised their fair share of challenges regarding the mass of documents concerned and the concrete possibility to process them, on the literary world, the book market, and the texts publication and reception. 
système de gestion documentaire que nous avons mis en place, dans la mesure où cette infrastructure n'est pas que fonctionnelle, elle contribue également à nous donner des repères qui peuvent constituer un indicateur des distorsions que toute synthèse tend à introduire. C'est dans cette optique qu'il apparaît pertinent de nous attarder sur la dimension très concrète de notre façon de faire, au modus operandi de chacun des tomes, appliqué méthodiquement à chaque cycle de production et à chaque tranche historique.

La production de chacun des volumes commence ainsi par des listes et des inventaires : des œuvres (par genres), des périodiques, des acteurs de la vie littéraire (écrivains, éditeurs, journalistes, professeurs, gens de théâtre, etc.), des associations, des bibliographies de sources secondaires portant sur la période, et des chronologies générales et culturelles du Québec et du Canada, de l'Amérique du Nord et de l'Europe. La première intelligibilité globale d'une tranche historique de La Vie littéraire provient de l'interprétation croisée de ces listes. C'est à partir de cette perspective commune et globale que nous nous partageons ensuite la responsabilité du plan et des premières versions du texte en fonction de nos spécialités (ou non !) et de la table des matières des tomes. La masse documentaire qui constitue notre point de départ (liste des acteurs, liste des œuvres, dossiers thématiques et bibliographie des sources secondaires) est ainsi organisée en fonction de sept chapitres, qui restent les mêmes tout au long la série ${ }^{2}$. L'ordre de chapitres reflète notre conception du processus par lequel la vie littéraire se déploie, allant de son inscription dans un paradigme littéraire international, de son

2 Ce sont 1. Les déterminations étrangères ; 2. Les conditions générales 3. Les agents de la vie littéraire ; 4. Le marché de la littérature ; 5 . La prose d'idées ; 6 . Les textes d'imagination ; 7. La réception of the document management system we set up insofar as this infrastructure is not only functional: it also contributes to giving us pointers that may serve as indicators of the distortions that all syntheses tend to introduce. For these purposes, we will look in very concrete detail at the $\mathrm{MO}$ adopted for each volume, which we methodically applied to each production cycle and each historical period.

The production of each volume begins with lists and inventories: of works (by genre); periodicals; actors of literary life (writers, publishers, journalists, professors, theatre professionals, etc.); associations; bibliographies of secondary sources on the period in question; and general and cultural chronologies on Quebec, Canada, North America, and Europe. Our first general understanding of a historical period for La Vie littéraire comes from the cross-interpretation of these lists. Based on this common and overarching perspective, we then divide the work of producing an outline and first versions of the text between the team members based on our specialties (or not!) and on the table of contents. The mass of documents we use as a starting point (lists of actors and works, thematic folders, and bibliographies of secondary sources) is organized according to the unchanging seven chapters of the series. $^{2}$ The order of the chapters reflects our perception of the process through which literary life unfolds, from its inscription in an international literary paradigm, and its dependence on socioeconomic and artistic conditions, with individuals organized in networks and forming a milieu, to the way it is structured as a

2 The list of chapters is as follows: 1 Foreign Determinants; 2 Genera Conditions; 3 . The Agents of Literary Life; 4 . The Literary Market; 5 . Ideas in Prose; 6. Imagination in Writing; 7. Reception. 
ancrage dans des conditions socioéconomiques et artistiques, se déployant par des individus qui s'organisent en réseaux et forment un milieu, en passant par sa structuration en un marché, et son inscription dans des œuvres, qui donnent ensuite lieu à une réception. Nous concevons ce mouvement comme agissant à la manière d'une spirale, dans la mesure où la réception des œuvres qui marque l'aboutissement d'un tome irrigue les conditions sociolittéraires et artistiques qui constitueront le point de départ du suivant. C'est sur la base de ces opérations, entrecroisées et interdépendantes, que nous avons modelé notre base de données.

\section{La base, sa structure et ses potentialités}

Les principales composantes de notre base sont regroupées sous les onglets "Documentation » et « Fiches », lesquels se trouvent à l'origine des tomes de La Vie littéraire comme au fondement du développement de notre écosystème numérique ${ }^{3}$.

L'espace « Documentation » constitue un lieu de stockage de fichiers nécessaires aux chercheurs pour rédiger les sections de l'ouvrage dont ils sont responsables. Nous organisons d'entrée de jeu cette documentation en trois sous-sections qui correspondent aux besoins de notre projet. La première rend disponible la numérisation des dossiers de documentation correspondant à chaque soustitre de notre table des matières, à chaque liste de dossiers ayant

3 Du point de vue technique, notre base relationnelle a été conçue à l'aide de logiciels Open Source et gratuits. Son interface de gestion et de consultation a été développée en utilisant les langages de programmations PHP et Javascript, et le système de gestion de la base de données ellemême est MariaDB, une variante totalement libre de MySQL. L'emploi de la technologie MariaDB/MySQL facilite grandement la diffusion de nos données, contrairement à une solution propriétaire de type FileMaker. market and materialized in texts that are subject to a reception We see this movement as a spiral, insofar as the reception, examined at the end of one volume, informs the socio-literary and artistic conditions discussed at the beginning of the next volume. We developed our database on the basis of these interwoven and interdependent operations.

\section{The Database, its Structure and Potentialities}

The main components of our database are found under the tabs "Documentation" and "Fact sheets" (Fiches in French). They are crucial both to the volumes of $L a$ Vie litterraire and to the development of our digital ecosystem. ${ }^{3}$

"Documentation" is a space to store the files needed by researchers to write their sections of the book. The documentation is divided into three sub-sections which fit the needs of our project. The first contains the digital version of the documentation folders matching each subtitle in our table of contents and each list of folders produced over time by the VLQ team to be used for the writing of volume 7

3 We built our relational database using free open-source software. The management and search interface was developed using the PHP and Javascript programming languages; and the database management system is MariaDB, a completely free version of MySQL. The use of MariaDB/MySQL technology greatly facilitates the diffusion of our data, unlike proprietary systems such as FileMaker. 
été produits au fil du temps par l'équipe de la VLQ et sur lesquels s'appuie la rédaction des tomes 7 et $8^{4}$. En prenant pour exemple le dossier virtuel "L'édition littéraire ", il est possible de constater que la manipulation de ces dossiers permet, d'une part, d'accéder à un PDF complet de l'ensemble des documents contenus dans ces derniers ou, d'autre part, de cibler, à partir de la liste de ces documents, celui ou ceux qui nous intéressent plus spécifiquement, par exemple les textes signés de la plume de Claude-Henri Grignon mieux connu sous le pseudonyme de "Valdombre ». and $8 .{ }^{4}$ For instance, the virtual folder on "Literary Publishing" gives access to a complete PDF file containing the names of all documents found in those volumes, and provides the opportunity to conduct a targeted search within the list of these documents to find the one(s) we might be more specifically interested in, such as, for instance, the texts penned by Claude-Henri Grignon, better known under the alias "Valdombre."

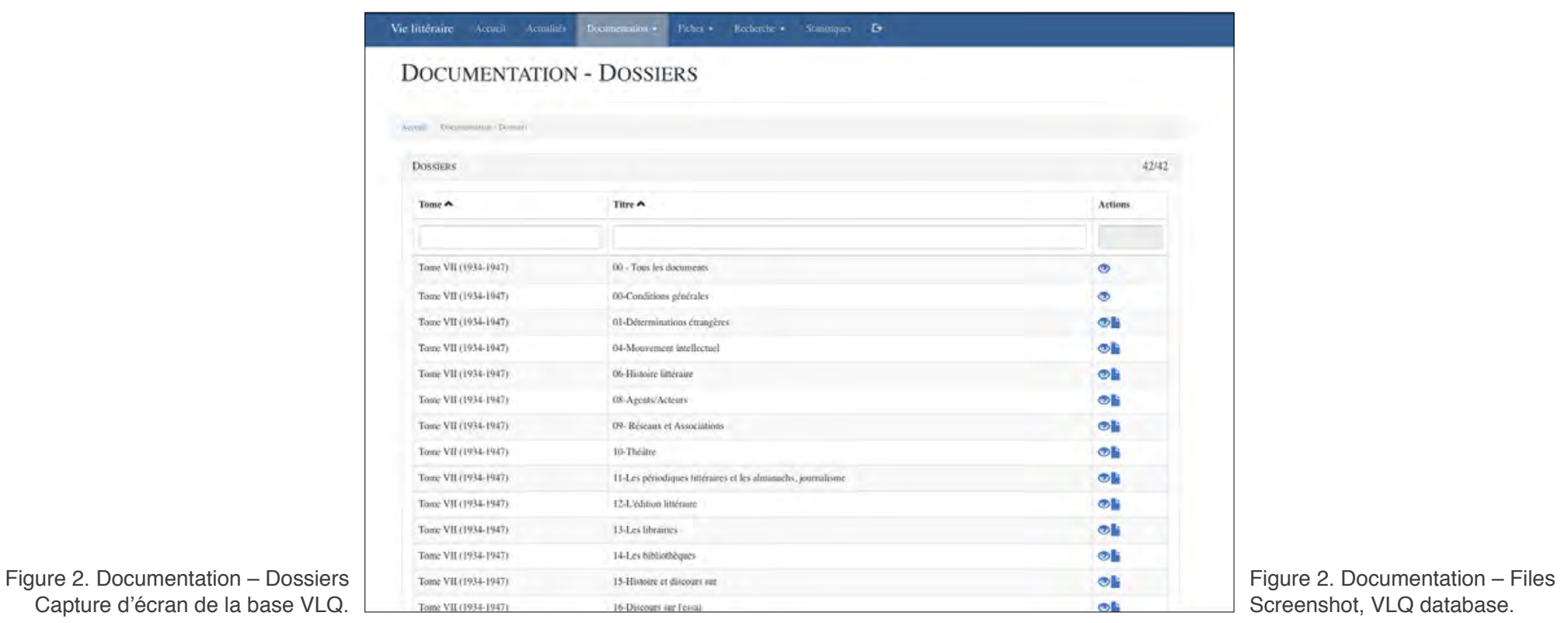

4 Cette documentation provient des dépouillements de périodiques que nous effectuons pour chacun des tomes de notre ouvrage, soit 250 à 300 périodiques par tome. Une fois compulsés, sélectionnés, numérisés et indexés, les articles sont intégrés dans la soixantaine de dossiers thématiques que nous avons établis.

4 This documentation comes from the analysis of periodicals that we conduct for each volume (ca. 250-300 periodicals per volume). Once we have consulted, selected, digitalized, and indexed them, the articles are included in one of around sixty thematic folders. 
Figure 3. Documentation - Dossier $n^{\circ} 12$ ("L'édition littéraire ») du tome VII (1934-1947) de La Vie littéraire au

Capture d'écran de la base VLQ.

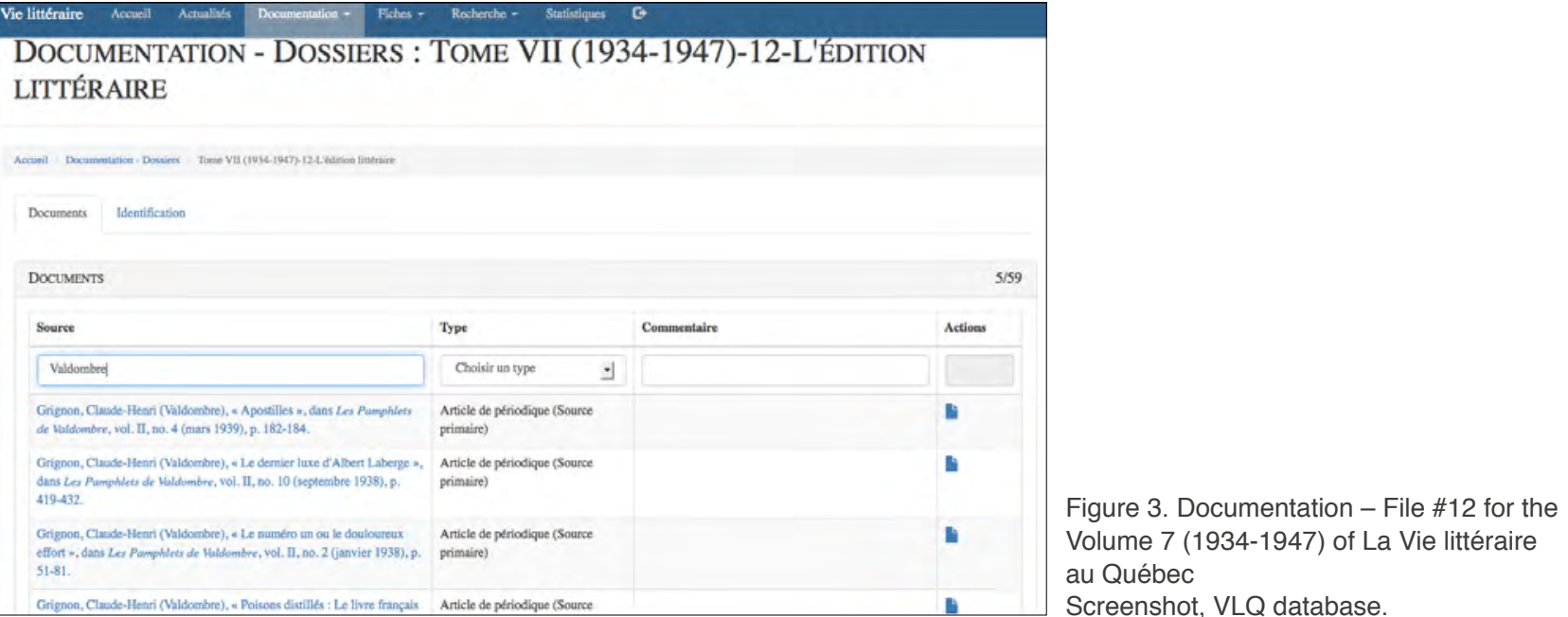

L'autre sous-section de l'espace «Documentation » contient des dossiers rassemblant de l'iconographie, accumulée au terme d'une première recherche systématique et au fil de trouvailles ponctuelles (plus de 250 images jusqu'ici). Les images serviront en bout de roue à illustrer chacune des parties, toujours en fonction de la table des matières, des prochains tomes de la VLQ.

La troisième et dernière sous-section, enfin, rassemble divers documents produits par les membres de notre équipe : des rapports réalisés par les étudiants dans le cadre de séminaires de recherche associés au projet, des documents administratifs issus de nos réunions et autres activités scientifiques, des dossiers de presse concernant des événements, des acteurs ou des prix littéraires, des annuaires de différentes institutions académiques, des numérisations d'extraits d'ouvrages ou de périodiques, etc. Bref, ce sont des documents utilisés par les chercheurs et les étudiants associés au projet : au-delà de leur intérêt pour documenter une
The other sub-section in the "Documentation" space contains folders featuring iconographic material accumulated during an initial systematic research stage, complemented by occasional findings (currently more than 250 images). The images will eventually be used to illustrate each of the parts of the next volumes of VLQ - again following the table of contents.

Lastly, the third and final sub-section includes a variety of documents produced by the members of our team: reports drafted by students for research seminars associated with the project; administrative materials from our meetings and other scientific activities; press kits on literary events, actors or prizes; directories of academic institutions; and digitalized excerpts from books or periodicals, etc. In short, these are documents used by the researchers and students involved in the project: beyond their interest for the purposes of documenting a specific section, they are liable to inform our common reading of a given period as well as the 
section spécifique, ils sont susceptibles d'informer la lecture commune que nous faisons de la période, puis la rédaction proprement dite des tomes, d'un article ou d'une présentation par un membre de l'équipe. La création et le développement de la base, conjugués à l'important (et lourd) travail de numérisation réalisé par le secrétariat central et permanent de l'équipe, ont permis de faciliter la consultation de ce très riche stock documentaire et, surtout, de maximiser son utilisation par l'ensemble des chercheurs associés au projet ${ }^{5}$, en tout temps et en tout lieu ${ }^{6}$ writing of the volumes or of an article or presentation by a team member. The creation and development of the database, alongside the considerable digitalization effort by the team's full-time central secretariat, have facilitated the consultation of this huge wealth of documents and allowed us to maximize their use for all researchers working on the project ${ }^{5}$ at any time and from anywhere. ${ }^{6}$

Figure 4. Quatre comédiens du radioroman Un homme et son péché " de Claude-Henri Grignon jouant sur les ondes de la station CBC (Radio-Canada) à Montreal Hector Charland (Séraphin Poudrier), Juliette Béliveau, Paul Guèvremont et George Alexander. Source : Fonds de Conrad Poirier, 1912-1968, 22 février 1945, BAnQ-Montréal, P48, S1, P23122.

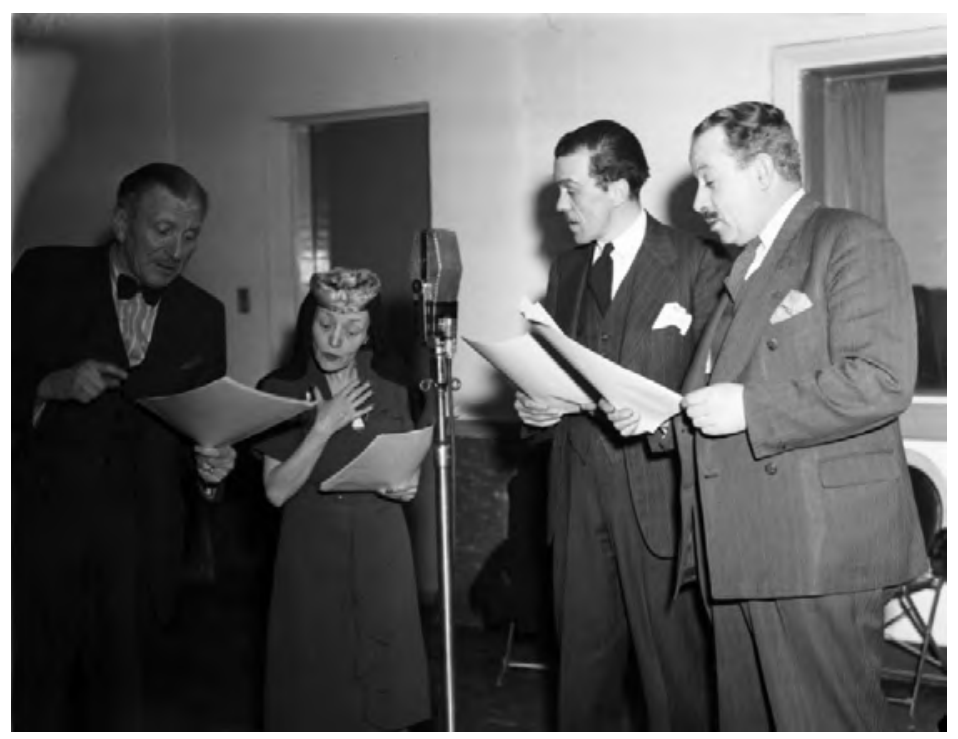

Figure 4. Four comedians acting in the radio adaptation of the novel "A Man And His Sin" by Claude-Henri Grignon, for the CBC (Radio-Canada) station in Montreal From left to right: Hector Charland (Séraphin Poudrier), Juliette Béliveau, Paul Guèvremont and George Alexander.

Source: Fonds de Conrad Poirier, 1912-1968, 22 février 1945, BAnQ-Montréal, P48, S1, P23122.

5 Auparavant, les dossiers de documentation au format papier étaient envoyés à chacun des rédacteurs en fonction de leurs responsabilités et des chapitres à rédiger.

6 Rappelons que le projet est interuniversitaire depuis son origine et qu'll rassemble maintenant douze chercheurs provenant de six établissements distincts

5 Previously, folders of documents were sent in paper form to each of the writers, according to the chapters they had been assigned.

6 The project has involved multiple universities from its inception, and now brings together twelve scholars from six establishments. 
Constituant le cœur de la base VLQ, l'espace « Fiches » contient, quant à lui, une vaste quantité d'informations concernant cinq types d'objets liés d'une façon ou d'une autre à la vie littéraire : les acteurs, les associations, les organismes, les lieux et les périodiques. Ici, il ne s'agit plus uniquement de documents numérisés, mais bien plutôt de données structurées.
The "Fact sheets" space forms the core of the VLQ database. It contains a wealth of information pertaining to five types of object relating to literary life in one way or another: actors, associations, organizations, places, and periodicals. These are not just digitalized documents, but structured datasets.

Figure 5. Fiche "Acteurs"

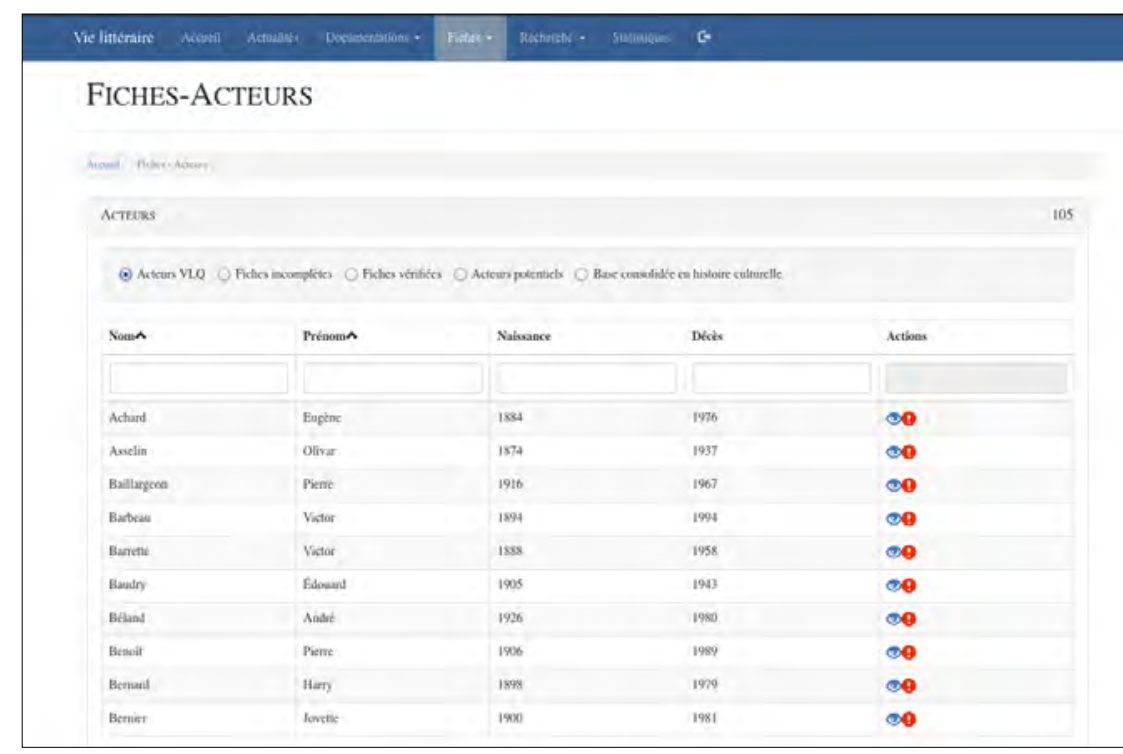

Au départ, la base de données de la VLQ n'était constituée que des fiches "Acteurs". Les quatre autres types d'objets n'existaient, en réalité, que comme des attributs de ces acteurs ${ }^{7}$. Or, au fil du processus d'adaptation de notre méthode aux possibilités ouvertes par les environnements numériques, nous avons entrepris de

7 Lionel Groulx était ainsi associé, par exemple, à une association, l'Académie canadienne-française, à un périodique, L'Action nationale, à un lieu, sa maison sur l'avenue Bloomfield à Outremont, etc.
Initially, the VLQ database solely contained fact sheets on "Actors." The four other types of object only existed as attributes of these actors. ${ }^{7}$ As we adjusted our method to benefit from the opportunities offered by digital environments, we decided to introduce individual fact sheets for each of these objects. This has allowed us not only

7 Lionel Groulx, for instance, was connected to an association - the Académie canadienne-française - a periodical - L'Action nationale - and a place - his house on the Avenue Bloomfield in Outremont, etc. 
créer des fiches indépendantes pour chacun de ces objets. Cela nous permet non seulement d'enrichir notre inventaire de renseignements, de références et de sources documentaires liés à ces fiches, mais également de croiser un ensemble de données encore plus englobant et efficient. to enrich our inventory of information, references, and documentary sources, but also to cross-reference a wider, more efficient set of data.

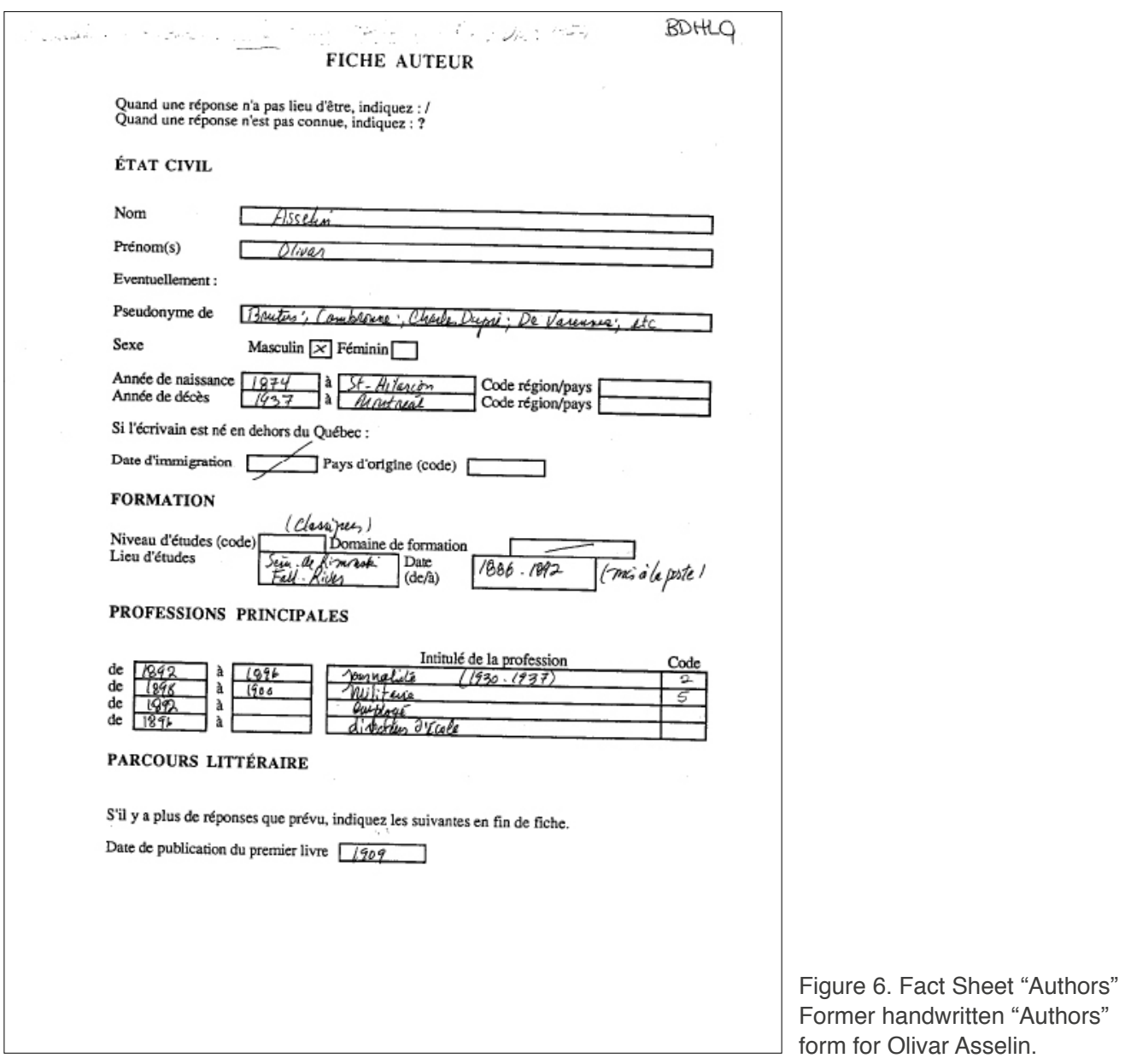


Au fil du temps, les fiches «Acteurs », visant à concevoir des échantillonnages ${ }^{8}$ sous forme de tableaux publiés dans les tomes, ont elles-mêmes évolué. En effet, si les principales catégories contenues dans les fiches papier originales (année de naissance et de décès, formation, occupations principales, publications, etc.), ont été répercutées dans nos fiches électroniques, certaines ont également été ajoutées afin de faciliter le recensement de nouvelles informations ou de nouvelles pistes à suivre (tels différents marqueurs de l'habitus et de la notoriété, le répertoire des groupes ou des lieux fréquentés par un acteur, ainsi que sa mention, ou non, dans les principales histoires littéraires du $x x^{e}$ siècle). En somme, il s'agit d'intégrer, à même les fiches, la possibilité de multiplier les requêtes, de les croiser, dans la perspective d'en élargir autant que d'en affiner les possibilités sur le plan statistique. Le tout pouvant bien sûr s'appliquer soit à la lecture générale de la période dans sa globalité, soit à un ensemble de données circonscrites (génération, genre littéraire, lieu d'activité, origine sociale, etc.). Si l'on compare, par exemple, la version papier de la fiche d'Olivar Asselin à sa version virtuelle, on constate que la seconde est en grande partie une reproduction de l'originale, mais que s'y ajoutent des informations conçues spécifiquement en vue de maximiser l'utilisation des outils de recherche et le repérage de corrélations

jusque-là inédites.

8 Ceux-ci représentent entre 100 et 150 acteurs retenus par tome, pour lesquels l'équipe a dû chaque fois se donner des critères de sélection en fonction d'une liste de base ne cessant de s'élargir. Par exemple, pour le tome 7 , cette liste de base comportait plus de 400 acteurs et nous nous sommes donc imposés une règle visant à discriminer les acteurs n'ayant pas publié trois livres ou plus. Par contre, nous avons également pris en compte d'autres acteurs importants ne répondant pas à cette règle, dont les gens de théâtre ou les éditeurs.
Over time, the fact sheets on "Actors," which were aimed at designing sampling 8 in the form of tables published in each volume, have also evolved. While the main categories contained in the original paper fact sheets (year of birth and death, training, main occupations, publications, etc.) were transferred to our digital sheets, some were also added to facilitate the inventorying of new information or avenues of research to follow (including a variety of indicators on habitus and fame, the list of groups or places frequented by actors, and their mention or lack thereof in the main literary histories of the twentieth century). The point is to be able to carry out multiple cross-searches between sheets, to broaden and refine their statistical opportunities. These searches may of course apply to a general overview of the entire period or to a limited dataset (on generation, literary genre, place of work, social background, etc.). If we compare, for instance, the paper version of the fact sheet on Olivar Asselin to the digital version, we can see that the latter is to a large extent a reproduction of the original, but that it has additional information devised specifically to make the most of search tools and pinpoint previously unreported correlations.

8 These samples include 100 to 150 actors per volume, selected on different criteria each time as the lists of actors keeps getting longer. For instance, for volume 7 , the complete list contained over 400 actors, and we decided to only select actors who had published three books or more, with the exception of a few major actors, including theatre professionals and publishers. 
Le champ « Regroupements », notamment, permet ainsi la création rapide, à des fins d'analyse, de sous-corpus d'acteurs, Asselin étant assigné au regroupement "VLQ-CA-1870 ", qui réunit tous les acteurs nés entre 1870 et 1879 . En l'état actuel, notre base permet donc d'établir, de manière automatique, des trajectoires communes et des réseaux d'acteurs, de déterminer les publications par genre et par génération, ce qui représente une avancée majeure par rapport aux fiches initiales, qui ne permettaient de telles opérations qu'au terme de longues démarches artisanales, coûteuses en temps aussi bien qu'en ressources.
The "Groupings" field can rapidly create sub-corpuses of actors for analytical purposes. Asselin is listed in the "VLQ-CA-1870" grouping, which includes all actors born between 1870 and 1879. In its current form, our database allows users to automatically establish shared trajectories and actor networks and classify publications by genre and generation, which is a major step forward from the original fact sheets, where similar operations were only possible by way of a lengthy and resource-intensive effort.

Figure 7. Résultat de la requête « VLQ-CA-1870 », qui donne la liste de tous les auteurs actifs au Québec, nés entre 1870 et 1879

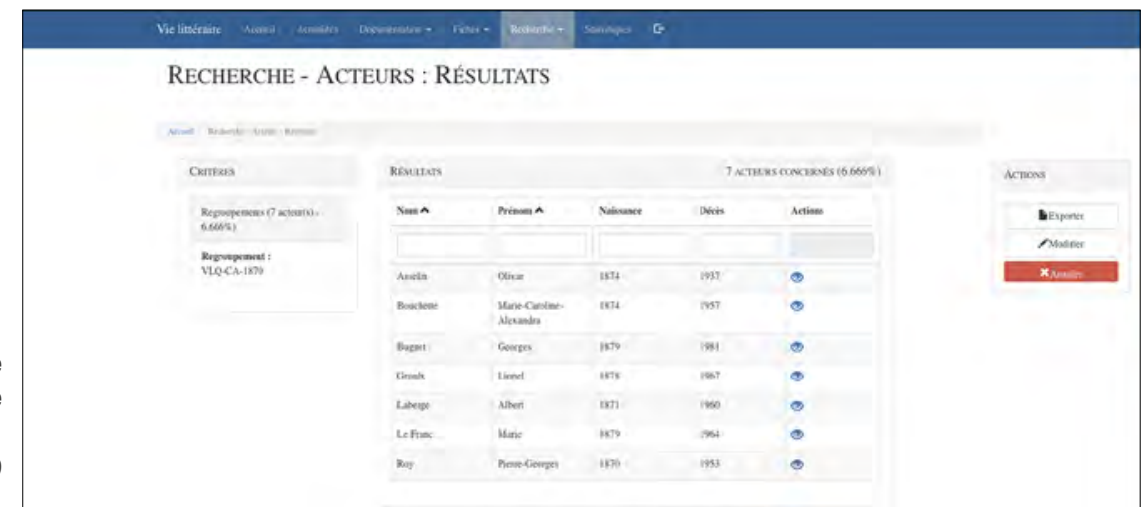

Figure 7. Result of the search "VLQ-CA-1870" which provides a list of every author active in Quebec, born between 1870 and 1879 Capture d'écran de la base VLQ.

Si les fiches «Acteurs 》 demeurent les fiches les plus détaillées et les plus complexes de notre base, des fiches d'autres types y sont désormais intégrées. Les fiches « CEuvres » contiennent les références bibliographiques des quelque 3000 œuvres - recensées à partir des catalogues de différentes bibliothèques et du Dictionnaire des cuvres littéraires du Québec (DOLQ) - grâce auxquelles chacun des collaborateurs entame son travail de sélection en vue de la rédaction de son ou de ses chapitres. Les fiches "CEuvres » permettent également de produire les tableaux statistiques (sur les nouveautés littéraires, les pourcentages de publications par

The fact sheets on "Actors" remain the most detailed and complex in the database, but other types of sheet are also featured. Those on "Works" contain bibliographical information on around 3,000 works compiled from several library catalogues and the Dictionnaire des cuvres littéraires du Québec (DOLQ). Thanks to these "Works" fact sheets, each of our collaborators can undertake the necessary selection process for the writing of their chapter(s); and produce statistical tables (on new literary releases, percentages of publication by genre, etc.), which are published in Chapter 4 of our volumes (on the literary market). The sheets on "Associations" 
genre, etc.) publiés dans le chapitre 4 (consacré au marché de la littérature) de nos tomes. Les fiches «Associations » comportent, pour leur part, des renseignements nous permettant de dresser le portrait le plus exhaustif possible des groupes culturels et littéraires, formels et informels, d'une époque donnée. Quant aux fiches "Périodiques », elles nous fournissent de l'information sur les dates et les contextes de fondation, sur les comités de rédaction, sur les tirages, etc., des journaux et des revues que nous avons choisi de dépouiller en fonction de nos critères et protocoles de recherche. include information allowing us to paint the most complete picture possible of the formal and informal cultural and literary groups in activity at a given time. The sheets on "Periodicals" provide information on the dates and contexts of the foundation of journals, selected on the basis of our criteria and research proposals, their editorial boards, circulation numbers, etc.

Figure 8. Fiche « Auteurs » numérisée pour Olivar Asselin Capture d'écran de la base VLQ.

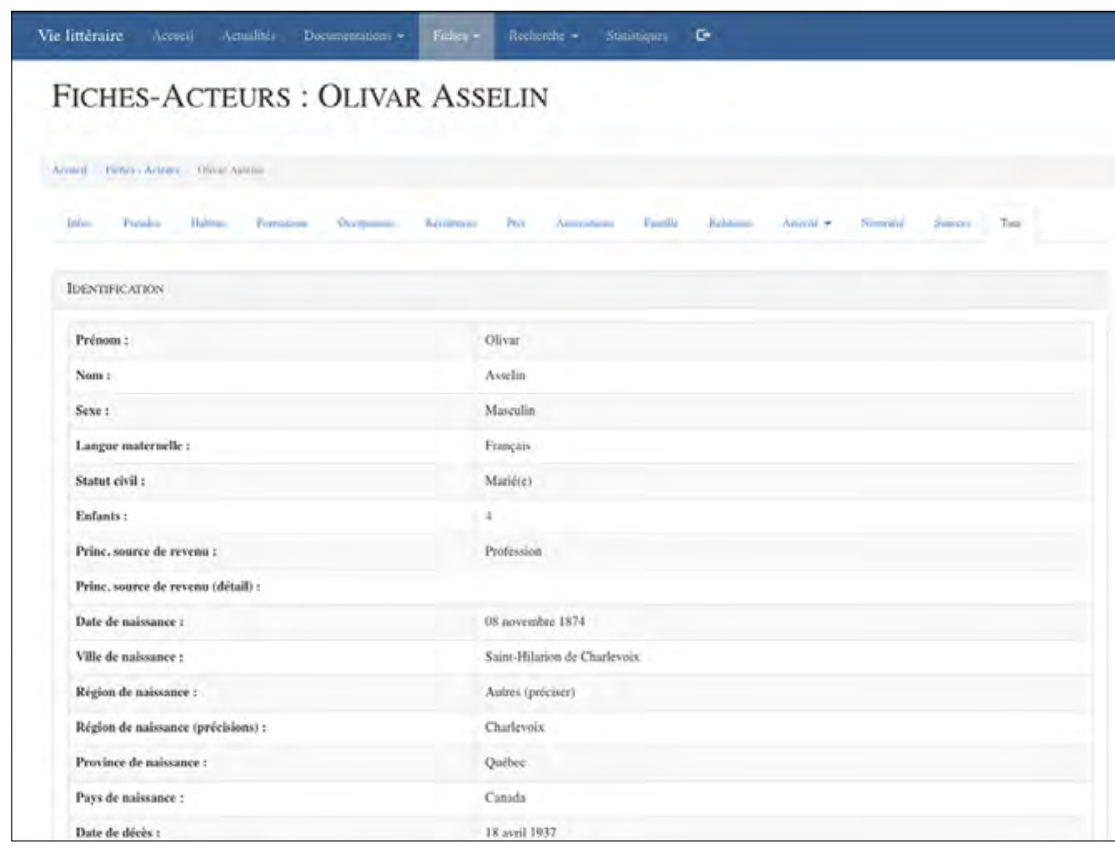

Figure 8. Digitalized "Authors" form for Olivar Asselin

Mais, plus que des sources, les périodiques sont également envisagés comme faisant partie du corpus des œuvres, et la prise en compte de cette double dynamique au sein de l'espace culturel est largement favorisée par la façon dont nous paramétrons les données, mais

Rather than simply sources, the periodicals are also considered to be part of the corpus of works. We account for this twofold dynamic in the cultural space thanks to the configuration of our data, but also and most importantly, to our ability to raise multiple 
surtout par la façon dont nous générons de multiples interrogations croisées à partir de ces dernières. On sait, par exemple, que dans les années 1930-1940, des revues intellectuelles importantes, telles La Relève ou Amérique française, définissent le rapport de plusieurs écrivains à la littérature en créant des communautés d'auteurs et en publiant leurs articles. De même, nous nous devons de prendre en compte l'avènement des magazines qui, du côté de la littérature populaire, ont un grand impact sur le champ littéraire de l'époque. Nous avons en outre carrément numérisé certains périodiques qui n'étaient toujours pas accessibles en ligne - malgré les efforts remarquables de la Bibliothèque et des Archives nationales du Québec (BAnQ) à cet égard - afin de pouvoir travailler efficacement dans cette masse documentaire souvent inédite, comme c'est le cas notamment de Radiomonde ${ }^{9}$ et Current Events ${ }^{10}$

Le passage au numérique est venu accroître la quantité d'interrogations originales que nous pouvons esquisser, de même que la vitesse à laquelle nous pouvons les vérifier. Cette malléabilité accroit significativement notre capacité à renouveler la compréhension de la vie culturelle d'une époque dans une perspective intégratrice, du point de vue de son déploiement in vivo et in situ. Ainsi, par exemple, on peut verser les données de la base renvoyant à la participation des acteurs à des lieux de sociabilité dans des logiciels d'analyse structurale des réseaux pour permettre l'analyse de la structure et de la force des réseaux de sociabilité entretenus par les acteurs de notre corpus. Ainsi

9 Bimensuel publié à Montréal entre 1939 et 1952, Radiomonde fait la promotion des artistes canadiens-français et de la vie culturelle montréalaise.

10 Initialement destiné aux touristes des grands hôtels montréalais I'hebdomadaire Current Events (1922-1976) recensait ce qu'il fallait voir et savoir sur Montréal (soirées dansantes, théâtre, cinéma américain, restaurants, etc.) interrelated questions pertaining to the data. We know, for instance, that in the 1930-1940s, major intellectual journals such as La Relève or Amérique française defined the relationship to literature of several writers by creating communities of authors and publishing their articles. Likewise, we must also take into account the rise of magazines, which had a major impact on the literary field in terms of popular literature. We went so far as to digitalize some periodicals not yet available online - despite the remarkable efforts of the Bibliothèque et Archives nationales du Québec (BAnQ) on that front - to be able to efficiently comb through that mass of often previously unsearchable documents such as the back issues of Radiomonde ${ }^{9}$ and Current Events. ${ }^{10}$

With the transition to digital, we were able to consider an increased number of original questions and verify them more quickly. This has made it significantly easier for us to gain a new understanding of the cultural life of a given era from an inclusive perspective, accounting for the way it unfolded in vivo and in situ. Our data on the participation of actors in venues of sociability can for instance be fed into structural network analysis software to analyse the structure and strength of these networks of sociability. This is also the case for data that lend themselves to geolocation. The website's section on "Places" offers access to maps, including one that presents the geographical locations of a wide variety of organizations relating to Montreal's literary life between 1934 and 1947 and one that

9 A bi-monthly magazine published in Montreal between 1939 and 1952 Radiomonde promoted French Canadian artists and Montreal's cultural life.

10 Initially geared toward tourists staying in Montreal's top hotels, the weekly Current Events (1922-1976) listed cultural events and addresses in the city (dance, theatre, American movies, restaurants, etc.). 
en est-il, aussi, des données pouvant être géolocalisées. La section "Lieux » du site donne accès à des cartes, par exemple celle qui présente la distribution géographique d'une multitude d'organismes liés à la vie littéraire montréalaise de 1934 à 1947 ou celle qui montre la répartition géographique des membres de deux regroupements importants, la section française de la Société royale du Canada et l'Académie canadienne-française. shows the geographical distribution of the members of two major groups, the French section of the Royal Society of Canada and the Académie canadienne-française.

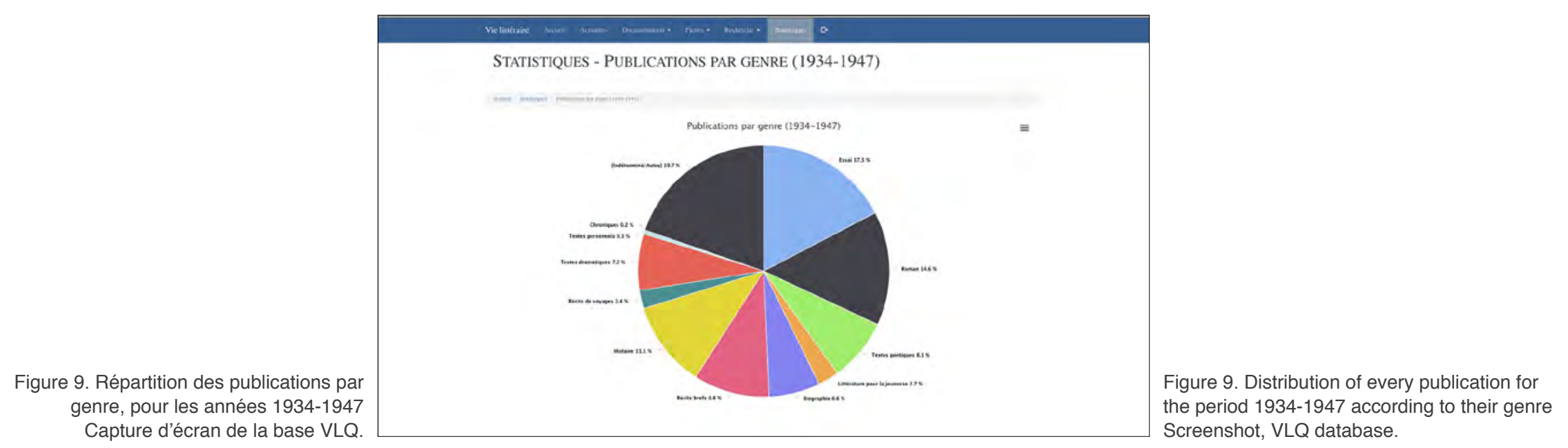

La production de nombreux graphes fait maintenant partie de plusieurs étapes de notre travail. Si nos « tableaux » des acteurs reflètent notre méthode et incarnent notre signature intellectuelle depuis le premier volume de la série, les besoins du resserrement de notre synthèse se sont déjà fait sentir et nous avons pour le tome VI, par exemple, jugé utile de présenter sous la forme de listes certains tableaux mettant en valeur les enjeux générationnels au sein de notre cohorte d'acteurs. Ce sont maintenant à peu près toutes les sections qui nécessiteront de transiter par des " cartes, graphes et arbres », pour reprendre le titre de Franco Moretti (2008). Notre travail sur les tomes en cours de préparation repose ainsi de plus en plus sur des données mises
Several stages of our work now entail the production of numerous graphs. While our "tables" on actors have reflected our method and been our intellectual signature since the first volume of the series, there has been a growing need to present tighter syntheses. In volume 6 , for instance, we decided to present in the form of lists, some of the tables which emphasized our cohort of actors' specific generational issues. Nearly all sections now require "graphs, maps, trees," to borrow a title by Franco Moretti (2005). Our work on the upcoming volumes increasingly relies on data presented in table form, some for internal use and intended primarily for interpretation purposes, others to be featured in the volumes to synthesize various 
en forme dans des tableaux, certains internes à l'équipe et destinés avant tout au travail d'interprétation, alors que d'autres seront utilisées dans les tomes eux-mêmes pour synthétiser différents aspects de nos analyses. Servant à illustrer notre propos, ces représentations des données ne sont pas un système magique : elles sont utilisées à toutes les étapes de nos analyses, et nous servent à tester et à documenter différentes inférences. Ne seront reproduites, au final, que celles ayant été validées et nous semblant offrir une vue éloquente sur la matière que nous avons compulsée. Soulignons enfin que la possibilité de vérifier plus rapidement la validité de nos inférences, de les affiner, de les ajuster, n'est pas qu'une question d'efficacité. Elle accélère en effet significativement le processus de la rétroaction et nous donne l'occasion de nous pencher, collectivement, sur de plus imposantes séries d'hypothèses. Cette possibilité s'avère ainsi un prolongement de la méthode collégiale qui caractérise l'équipe ${ }^{11}$.

\section{Seuils et réduction}

Tels que nous venons de les évoquer, les principes qui sont à la base de notre collecte de données et de leur organisation en fonction de la table des matières de nos ouvrages sont à la fois reflétés et décuplés par leur utilisation dans le contexte d'un environnement numérique. Les croisements interprétatifs multilatéraux, la rétroaction rendue possible par l'accélération du processus de production d'inférences interprétatives puis de validation des hypothèses viennent cependant avec un accroissement substantiel de toutes les données que nous considérons pour réaliser notre histoire de la

11 Rappelons que la série La Vie littéraire au Québec ne présente pas une juxtaposition de textes signés individuellement. Reflétant notre processus de travail collectif à toutes les étapes, depuis la recherche jusqu'à la publication, les tomes sont signés collectivement : les noms des membres de l'équipe sont ainsi mentionnés sur la page de titre des ouvrages. aspects of our analysis. These representations of data are not a magical system: we use them to illustrate our argument at each step, and to test and document a variety of inferences. We only include those that have been validated and appear to give insight into our subject matter. Lastly, it is worth noting that this opportunity to verify the validity of our inferences, to refine and adjust them, is not only a matter of efficiency. Indeed, it significantly speeds up the retroaction process and gives us a chance to collectively consider larger series of hypotheses in a way that suits the collaborative working method that characterizes our team. ${ }^{11}$

\section{Quantitative Thresholds}

These founding principles of our data collection and of their organization on the basis of our table of contents are both reflected and augmented by their implementation in a digital environment. The multilateral cross-interpretations and the retroaction made possible by the acceleration of the process through which interpretative inferences are produced and hypotheses are validated come with a substantial increase in the amount of data we consider in the making of our history of literary life. Acceleration and refinement are often perceived as positive aspects, but they remain limited by

11 The series La Vie littéraire au Québec is not a collection of individual texts The volumes are authored collectively to reflect our collective working process at every step - the name of the team members appears on the title page. 
vie littéraire. L'accélération et le raffinement, souvent perçus dans une perspective méliorative, restent contraints par le principe de synthèse et la réduction à laquelle ce principe nous astreint. C'est de cet aspect, qui vient introduire une force contraire au processus, que nous entendons maintenant rendre compte. the synthesis and reduction required by our principles. This section addresses this counterweight.

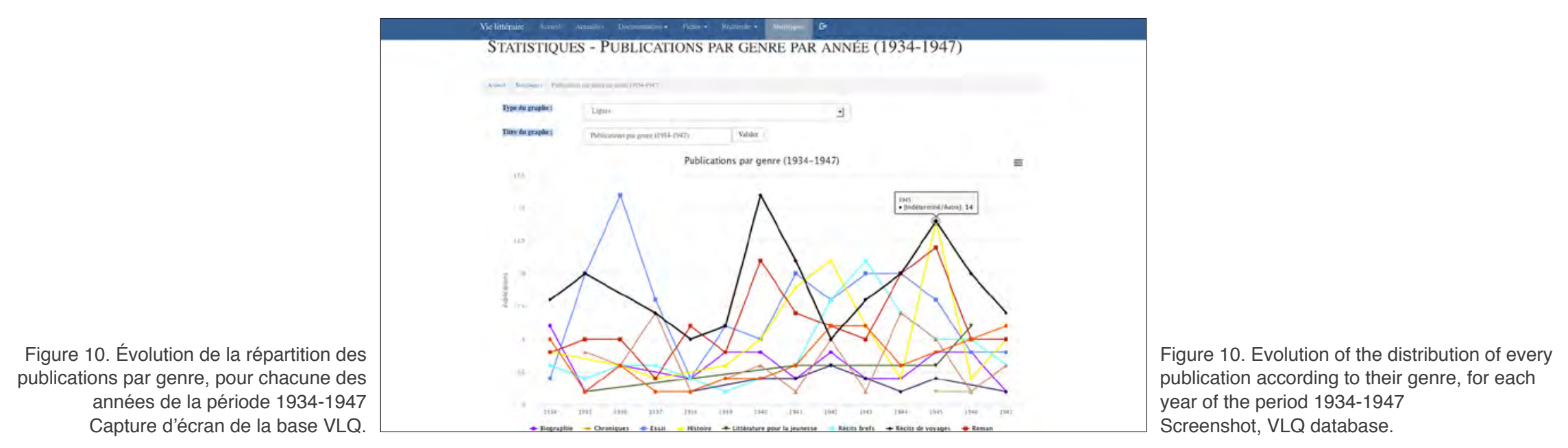

Les indicateurs qui fondent notre démarche et structurent notre propos sont ceux auxquels ont recours les travaux d'histoire et de sociologie de la littérature, et que Gisèle Sapiro présente en deux grands ensembles : ceux qui portent sur « la production et la circulation des livres et de l'imprimé, leurs publics et leurs usages ", et ceux qui « prennent pour objet le monde des lettres, son recrutement social, sa structure, ses instances de consécration, ses modes de hiérarchisation et les œuvres elles-mêmes » (2008: 35). La spécificité de notre travail réside plutôt dans la prise en compte de l'ensemble du processus par lequel se constitue la vie littéraire pour chaque période et dans cette globalité à laquelle nous tenons et à laquelle nous nous référons constamment.
The indicators on which our approach and argument are based are those used in research on the history and sociology of literature, and that Gisèle Sapiro divided into two main sets: the indicators on "the production and circulation of books and printed materials, their publics and uses" on the one hand, and those that focus on "the world of letters, its social recruitment, structure, consecration bodies, forms of hierarchization, and the works themselves" (2008: 35 ) on the other hand. The specificity of our research resides in the fact that we consider the entire process through which literary life is built in each period and in our continual references to this context. 
Mais, au-delà des mesures du littéraire et des habituelles applications des méthodes quantitatives à nos objets de recherche, la contrainte de la synthèse que nous nous sommes imposée s'est progressivement amplifiée. Elle atteint maintenant un degré qui accroit la nécessité d'une dimension métaréflexive surplombante, exercice qui nous permet de constamment équilibrer les deux forces opposées qui s'exercent sur notre travail en nous recentrant sur nos objectifs, nos méthodes et nos possibilités. Centré sur la notion de « vie ", théorisée depuis par Lucie Robert (2012), le cœur du travail intellectuel réalisé dans le contexte de notre projet consiste à " mettre en relation des processus, des événements et des textes » (Présentation générale de La Vie littéraire au Québec : viii). Et c'est à partir de cinq processus déterminants - l'enseignement littéraire, l'autonomisation du milieu des créateurs (qui inclut le marché), la formation des frontières, le discours sur la littérature et la manifestation du littéraire dans les œuvres - que nous avons conçu l'ossature de notre table des matières pour chaque tranche chronologique, puis organisé l'indexation des sources en fonction de cette table, sorte de thésaurus qui permet d'organiser la documentation pour la ramener à une soixantaine de dossiers thématiques. Cette structure et ces dossiers incarnent très concrètement notre conception de l'histoire littéraire du Québec, « [qui] devrait se lire non comme un axe continu, allant de la production à la réception, mais plutôt comme une spirale

où le mouvement lui-même est facteur de changement » (xii).

\section{Tableau et table des matières}

Le tableau suivant, qui synthétise les différentes annexes de chacun de nos tomes, donne un aperçu de la mesure de l'effet de synthèse à l'œuvre dans notre histoire de la vie littéraire. Celuici peut en effet servir de repère pour esquisser l'observation de
However, beyond the measurement of literature and the usual applications of quantitative methods to our research topics, our self-imposed constraint for synthesis has become increasingly pressing. It has now reached a degree that makes it even more necessary to include an overarching meta-reflexive dimension to the project, which serves as a means to constantly strike a balance between the two opposite forces that inform our work by refocusing our objectives, methods, and possibilities. Built around the concept of "life" as theorized by Lucie Robert (2012), the heart of the intellectual work in this project consists in "connecting processes, events, and texts" (general presentation of La Vie littéraire au Québec: viii). The backbone of our table of contents is made up of five key processes: literary teaching; the autonomization of the creators' milieu (which includes the market); the creation of boundaries between what is literature and what is not; and discourse on literature and the manifestation of literature in the works. We then organized the indexing of sources on the basis of this table, which serves as a thesaurus of sorts, to enable us to group our documents into around sixty thematic folders. This structure and these folders are concrete embodiments of our perception of Quebec's literary history, "[which] should be read not as a continuous line from production to reception, but rather as a spiral where movement itself is a factor of change" (xii).

\section{Tables and Table of Contents}

The following table, which synthetizes the appendixes in each of our volumes, gives us a glimpse into the synthesis effect at work in our history of literary life. It can be used as a reference point for 
la condensation/concentration progressive de quelques sources premières qui constituent des données de base de notre travail ${ }^{12}$.

\begin{tabular}{|r|c|c|c|c|c|c|}
\hline & Tome 1 & Tome 2 & Tome 3 & Tome 4 & Tome 5 & Tome 6 \\
\hline Personnes & 602 & 798 & 958 & 1233 & 1005 & 1087 \\
\hline CEuvres & 151 & 163 & 314 & 751 & 959 & 1282 \\
\hline Périodiques & 39 & 74 & 118 & 181 & 129 & 138 \\
\hline
\end{tabular}

Figure 11. Nombre de personnes, d'œuvres et de périodiques pris en compte dans les différents tomes de La Vie littéraire au Québec Ces chiffres ont été comptabilisés à partir des annexes des tomes de La Vie littéraire au Québec (index des noms de personnes, index des périodiques et section « CEuvres » de la bibliographie). Dans le cas des index, ceux-ci renvoient aux individus et aux journaux ou revues cités dans les ouvrages, sans distinction d'origine, ou, pour les personnes, de classe ou d'occupation. II s'agit donc de données brutes, à manipuler avec précaution, mais qui permettent de confirmer la croissance continue de la masse documentaire et de rendre visibles les seuils qui nous intéressent ici.

Nous commenterons peu la question de la croissance du nombre d'acteurs de la vie littéraire, cette matière ayant été couverte de manière plus détaillée dans un article signé par deux membres du collectif et qui porte sur nos analyses de cohortes d'acteurs :

La liste préliminaire du tome IV, couvrant les années 18701894, regroupait 210 noms, dont 115 ont été retenus dans l'échantillon d'analyse. Pour le tome $\mathrm{Vl}$, consacré aux années 1919-1933, pas moins de 580 individus avaient publié un livre; nous en avons retenu 135. Pour les années 19341947, sur lesquelles nous travaillons actuellement, la liste

12 II faut cependant se garder d'en tirer un propos simpliste : les chiffres que nous présentons ne constituent qu'une entrée en matière d'un exercice qui prendra une forme plus aboutie au terme du prochain cycle de subvention (celles que nous recevons du Conseil de recherches en sciences humaines du Canada, CRSH ; et du Fonds de recherche du Québec en société et culture FRQ-SC), celui qui permettra l'achèvement de nos deux derniers tomes et accompagnera le partage des données à l'issue de ce parcours qui aura duré plus de trente ans. the observation of the progressive condensation/concentration of a few primary sources that serve as baseline data for our work. ${ }^{12}$

\begin{tabular}{|r|c|c|c|c|c|c|}
\hline & Volume 1 & Volume 2 & Volume 3 & Volume 4 & Volume 5 & Volume 6 \\
\hline Persons & 602 & 798 & 958 & 1233 & 1005 & 1087 \\
\hline Works & 151 & 163 & 314 & 751 & 959 & 1282 \\
\hline Periodicals & 39 & 74 & 118 & 181 & 129 & 138 \\
\hline
\end{tabular}

Figure 11. Number of persons, works and periodicals taken into account in the different volumes of La Vie littéraire au Québec These numbers are derived from all the $L a$ Vie littéraire au Québec volumes' Appendix (composed of index of names, persons, newspapers, and journals, plus the "Works" section of the bibliography). These indexes refer to individuals and newspapers or journals mentioned in the books, wherever they are from, or (for the individuals) whatever their class or occupation are. This raw data therefore is to be interpreted cautiously, but it confirms the continuous increasing in the number of processed documents, and it clearly shows the thresholds on which we want to focus here.

We will not comment on the increase in the number of actors of literary life at length, as this issue was covered in greater detail in an article on our analysis of actor cohorts by two members of our collective:

The preliminary list for volume 4 , covering the years 1870 1894, contained 210 names, including 115 that were selected in our sample. For volume 6 (1919-1933), no fewer than 580 individuals had published a book; we selected 135 of them. For 1934-1947, on which we are currently working, the list of authors was simply too large: we had to restrict it by taking out all of those who had only published one or two

12 Here we must however refrain from indulging in simplistic interpretations: the numbers we present are only a starting point, and will be further refined by the end of the next funding cycle (with subsidies from Canada's Social Sciences and Humanities Research Council, SSHRC - CRSH, and from Québec's Research Fund on Society and Culture, FRQ-SC). By then we will have completed the last two volumes and made all relevant data available after more than thirty years of work. 
des auteurs d'un livre était tout simplement démesurée : nous avons donc dû la restreindre en écartant ceux qui n'avaient publié qu'un ou deux livres : nous nous sommes ainsi retrouvés avec une liste « préliminaire » de 475 auteurs d'au moins trois livres (Lacroix \& Savoie $2015: 191$ ).

Rappelons quand même que, si les chiffres compilés à partir des noms mentionnés dans l'index révèlent une certaine croissance, i faut surtout contextualiser cette augmentation par le fait que nous travaillons toujours, peu importe le nombre d'agents repérés dans le champ littéraire, sur un échantillon d'une centaine d'acteurs. La croissance que suggère notre tableau se fait ainsi hors de cet échantillon. On peut néanmoins en déduire que nous parlons de plus en plus, dans nos tomes récents, d'acteurs différents de ceux sélectionnés dans l'échantillon à partir duquel nous produisons nos analyses du personnel littéraire. Si elle peut sembler banale, cette constatation implique qu'on rende compte aussi de ce décalage qui se creuse à chaque tome et qui est partie prenante du processus d'autonomisation autant que de légitimité de la

littérature québécoise.

Une autre mesure du double mouvement de croissance et de réduction que notre travail nous mène à opérer se profile dans les statistiques concernant les entrées d'index et de bibliographies portant sur les œuvres et sur les périodiques. S'il y a en soi peu à ajouter, à cette étape de notre réflexion du moins, ces données montrent une augmentation assez nette, hormis un calcul statistique plus fin, qui quantifierait cette croissance. Mais, ce que nous souhaitons mettre à l'avant-plan tient plutôt à une tentative de mesure du traitement plus synthétique que nous devons faire de ces matériaux premiers. Pour concrétiser cet aspect et pour mettre à profit le principe de stabilité de notre table des matières qui reste à peu près inchangée d'un tome à l'autre, et ce malgré le fait que books; we ended up with a "preliminary" list of 475 authors of at least three books. (Lacroix \& Savoie 2015: 191)

Here we should point out that while the numbers compiled on the basis of names mentioned in the index undoubtedly reveal growth, this growth should be contextualized in light of the fact that we always work on a sample of around 100 actors regardless of the number of agents counted in the literary field. The growth suggested by our table is therefore something that happens outside our sample. We can nevertheless infer from this that in recent volumes, we increasingly discuss different actors from those selected in the sample that serves as the basis for our analysis of the literary world. While it may seem pedestrian, this observation means that we must also account for this gap, which widens with each volume and reflects the autonomization and legitimization process of Quebec's literature.

We can also get a sense of the double movement of growth and reduction required by our work from index entry statistics and bibliographies of works and periodicals. While there is little to add at this point, in the absence of finer statistical processing to quantify this growth more precisely, we can observe that these data show a fairly sharp increase. Here, we will discuss our attempt to gauge the more synthetic treatment that these raw materials require. Taking advantage of the fact that our table of contents remains roughly unchanged from one volume to the next, even though the first volume covered the years 1764-1805 and the most recent covers the interwar period, we will use the example of the section 
le premier tome couvre les années 1764-1805 et le plus récent paru celles de l'entre-deux-guerres, nous prendrons pour exemple les titres et sous-titres de la section du chapitre 6 (« Les textes de

l'imagination et de la subjectivité ») des 6 tomes parus.

Le premier tome, qui traite les années 1764 à 1805, sera couvert rapidement, les premiers romans paraissant sous forme de feuilletons au cours de la période du tome II. C'est cependant au tome III que nous poserons notre premier jalon, les années 18401869 , celles qui suivent le rapport Durham ${ }^{13}$, marquant un temps fort de l'histoire romanesque canadienne avec la parution de plusieurs classiques du $\mathrm{XIX} \mathrm{e}^{\mathrm{e}}$ siècle québécois. Essentiellement, la table des matières de la section « roman " du tome III qui s'étale des pages 398 à 421 (23 pages) présente les romans un par un les répartissant à peu près également dans les catégories " récit d'aventure ", « roman historique », « roman de mœurs et critique sociale ", suivant la chronologie de leur publication. Les sousentrées reprennent toutes des titres de romans uniques sauf deux, "Les romans d'Émile Chevalier », qui saisit une série par son auteur, et le « roman de mœurs en traduction », qui fait la même chose au fond mais sans nommer l'auteure et traductrice, Eleanora Mullins Leprohon. On voit déjà poindre deux régimes de textes et d'auteurs,

13 Dans son rapport de 1839 , qui suit immédiatement les Rébellions des Patriotes de 1837-1838 et qui vise à en expliciter les causes, John George Lambton comte de Durham propose une série de réformes controversées dont l'assimilation des Canadiens français par l'Union du Haut et du BasCanada qui adviendra en 1841. Néanmoins, la défense de l'idée d'autonomie politique, qu'il propose par son appui au gouvernement responsable que les Canadiens réclameront et obtiendront en 1848, marque une étape importante dans l'évolution de la démocratie au pays. Sa désormais célèbre injonction selon laquelle les Canadiens « sont un peuple sans histoire et sans littérature » agira comme une sorte de déclencheur pour les écrivains de l'époque. entitled "Works of Imagination and Subjectivity" from Chapter 6 in all six published volumes.

The first volume (1764-1805) was processed quickly as the first novels were published in serial form during the period covered by volume 2 . By volume 3 , we had to work on a more substantial corpus on novels. The years 1840-1869, which followed the Durham Report, ${ }^{13}$ marked a high point in Canada's literary history, with the publication of several classic nineteenth-century québécois novels. Essentially, the table of contents of the "Novels" section of volume 3 , spanning from page 398 to page 421 (twenty-three pages) presents the novels one by one, distributing them fairly evenly between the sub-categories "adventure novel," "historical novel," and "psychological novel and social critique," following the chronology of publication. The sub-entries all use the title of a single novel, except two, "The novels of Émile Chevalier," on a series of novels by the same author, and "The novel of manners in translation" - a similar case, albeit one which does not name the author and translator, Eleanora Mullins Leprohon. A distinction between two types of texts and authors is thus introduced, although

13 In his 1839 report, which aimed to shed light on the causes of the Patrio Rebellions of 1837-1838, John George Lambton, Earl of Durham, proposed a set of controversial reforms, including the assimilation of French Canadians through the unification of Upper and Lower Canada, which was implemented in 1841. Yet his support for the idea of political autonomy, as he recommended a responsible government that would be achieved in 1848 marked a landmark in the evolution of Canadian democracy. His now famous claim that French Canadians were "a people devoid of history and literature" was a trigger for many writers at the time. 
trois en considérant le fait que Mullins Leprohon est bien présente et tout aussi importante que les autres lorsqu'on lit le texte ${ }^{14}$.

Pour la période du tome $\mathrm{V}$ (1895-1918), on détecte une cinquantaine de romans publiés en volume, signés par une trentaine d'auteurs. Toujours en une vingtaine de pages de textes, la table des matières se découpe en trois grandes sections : "Poursuite des voies traditionnelles » (subdivisée en roman d'aventures et roman historique), "Renouvellements » (subdivisée en roman de mœurs politiques et roman social) et «Vers le roman du terroir ». Le principe chronologique domine, les auteurs et les titres disparaissent. Au fil du texte, si les catégories prédominent par la fonction des soustitres, la présentation par roman et par auteur est maintenue, avec cette fois une légère tendance à centrer davantage le propos par œuvre que par auteur, comme en témoigne le fait que la production de certains auteurs soit scindée lorsque les tendances révélées par l'apparition de nouveaux sous-genres l'exigeait. Sans doute voit-on déjà ici le principe du sous-genre littéraire prendre du galon et jouer un rôle de moteur pour décrire l'évolution des tendances plutôt que d'une catégorie stable. La tendance se poursuit au tome VI, tome pour lequel la table des matières est tout à fait semblable, tant dans ses découpages que dans sa dimension chronologico-générique, qui va de la continuité au renouvellement. Cette fois encore, ce ne sont plus les romans pris individuellement ou des séries d'auteurs qui sont considérés, mais plutôt des classements organiques, qui mettent en valeur notre manière de restituer la perspective de l'époque sur les œuvres («Le roman des conflits sociaux » ou « Le roman de la fidélité au féminin »), alors que le nombre de titres et d'auteurs mentionnés explicitement dans le corps du texte reste

14 Notons par ailleurs que c'est à la fois la seule femme dont il est question dans cette section, et que c'est également la seule auteure à ne pas figurer dans les tables des matières. it should be noted that Mullins Leprohon is mentioned to the same extent as the other authors in the text proper. ${ }^{14}$

For the period covered in volume 5 (1895-1918), we found some fifty novels published by around thirty authors. Still more than approximately twenty-page long, the table of contents is divided into three main sections: "Further down traditional paths" (with sub-sections on adventure novels and historical novels); "New developments" (with sub-sections on political novels of manners and social novels); and "Towards a home-grown novel." The chronological principle prevailed - authors and titles disappeared. In the text proper, while categories dominated as they are the subject of sub-sections, the presentation by novel and author was retained with a slight tendency towards a discussion by work as opposed to by author, as attested by the fact that the output of some authors was addressed in different sub-sections when the emergence of new sub-genres required it. This points to the growing importance of literary sub-genres, which have become more instrumental to the description of transformations than stable categories. The trend continues in volume 6 , whose table of contents is very similar both in terms of division by sections and its genre-based and chronological approach, from continuity to new developments. Again, organic classifications are preferred to the consideration of individual novels or series of authors, as they are better suited to our account of the era's perspective on the works ("Novels on social conflict," "Novels on female fidelity"). The number of works and authors explicitly mentioned in the text proper remained similar ${ }^{15}$. A new category - publishers - appeared in the

14 It should be noted that she is both the only woman addressed in the section and the only author that is not named in the table of contents.

15 There is, however, a tendency to associate an author with a group of texts of which he is considered an emblem; the difference lies in the designation of 


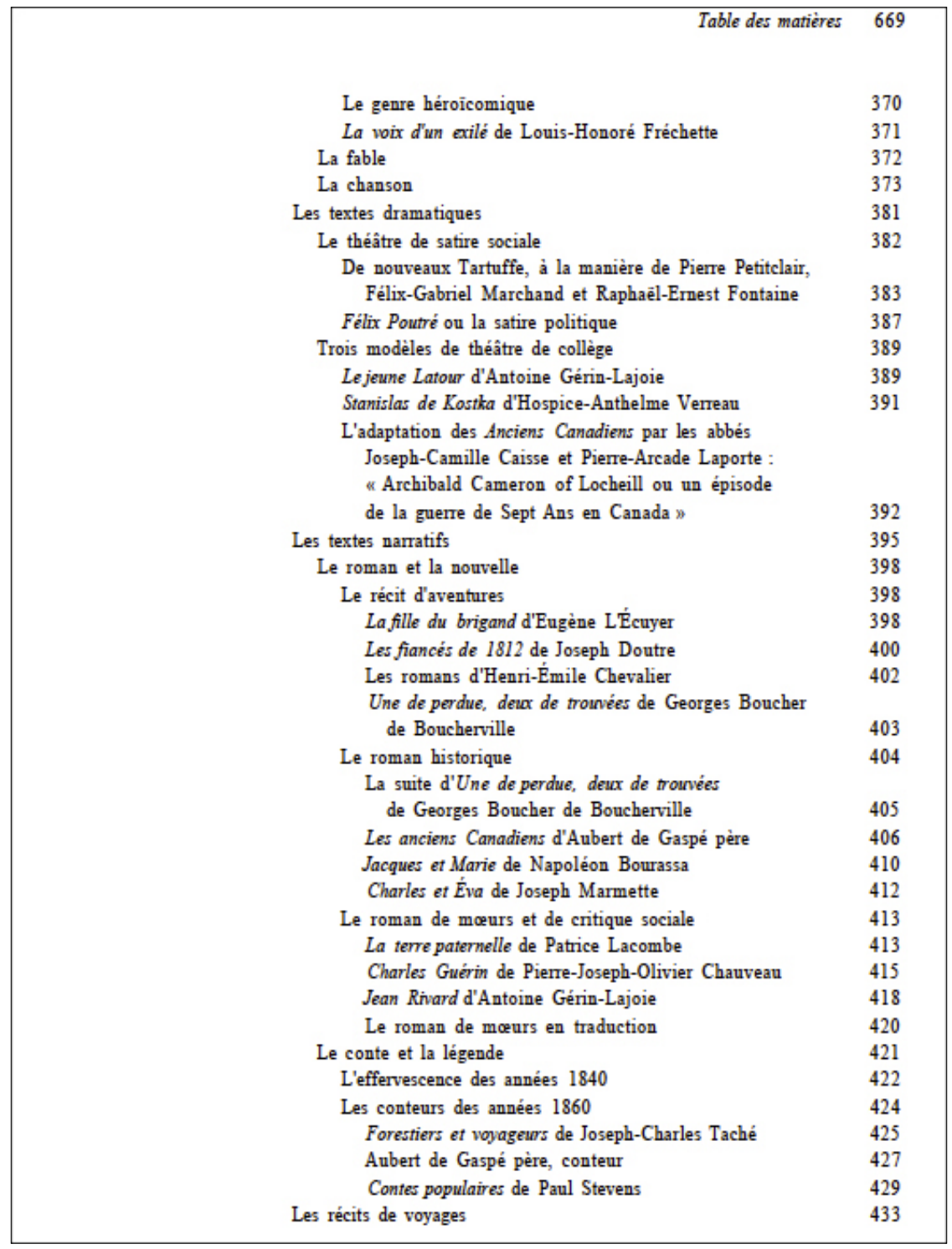

Figure 12. Table of Contents

Extract from the Table of Contents

of the "Novels" Section

(Volume 3 of La Vie littéraire au Québec). 
semblable ${ }^{15}$. Une nouvelle catégorie fait également son apparition pour organiser le texte, dans la partie couvrant les " nouvelles voies », celle des éditeurs. Sous les termes « Un projet d'éditeur » se cache en effet Édouard Garand, alors que la collection "Les romans de la jeune génération » permet de faire l'association avec

les éditions Albert Lévesque ${ }^{16}$.

\section{Conclusion}

Ce bref aperçu situe le virage numérique des travaux de l'équipe de La Vie littéraire dans le prolongement du principe de réduction engendré par les effets convergents de la croissance du volume de documentation et d'interactions, et du maintien d'un principe de synthèse globale qui est au cœur de notre mandat. Nous souhaitons, en terminant, en pointer trois aspects qui nous semblent importants. En premier lieu, la multiplication des interrogations croisées de nos données. Cet aspect est loin d'être strictement quantitatif, et nous en percevons déjà l'impact sur le nombre, sur le tri et, au final, sur la qualité des hypothèses que nous en venons à formuler. II nous permet de voir se profiler la multilatéralité des rapports qui existent entre les différents indicateurs que nous prenons en considération. En deuxième lieu, l'accélération du partage et de la mise en commun. Le principal impact de ce gain ne relève pas tant d'un "progrès " sur le plan de l'efficacité, ou d'une économie de temps en soi (le temps de production d'un tome ne s'est pas accéléré, loin de là !), que des avantages d'une perspective commune dont le processus s'amorce un peu plus en

15 On note quand même une tendance à associer un auteur et une série de textes dont le sien serait emblématique, la différence se situant plutôt dans la désignation de la série elle-même.

16 Les titres suggèrent déjà ici une conception du travail éditorial, notamment celui de rassembler des œuvres sur la base de parentés, en l'occurrence générique et générationnelle. section on "New Developments." "A Publisher's project" indeed refers to Édouard Garand, whereas the sub-section on "Novels of the young generation" features a discussion of the Albert Lévesque publishing house. ${ }^{16}$

\section{Conclusion}

This brief overview situates the digital transition experienced in the process of creating La Vie litteraire as an extension of the reduction principle resulting from the converging effects of the increasing volume of documentation and interactions under study, and of our efforts to keep offering an overall synthesis. To conclude, we wish to stress three aspects that we believe to be important. The first is the multiplication of cross-queries in our database. This is far from a strictly quantitative aspect; we can already perceive its impact on the number, selection, and ultimately the quality of the hypothesis we formulate. It gives us a window into the multilaterality of the relations between the indicators we take into consideration. The second is the acceleration of the pooling and sharing of data. The main impact of this time-gain is not so much about "progress" in terms of efficiency, or about saving time as such (the production of our volumes has not by any stretch become a quicker process). Instead, it benefits our collective approach, whose process can now begin at a slightly earlier point of the work. This phenomenon comes with heightened demands when it comes to interpretation, especially in the context of the dizzyingly vast amount of

this group of texts.

16 The headings themselves reflect our perceptions of editorial work, which entailed grouping works on the basis of affinities - here genre-based and generational. 
amont dans nos opérations. Ce phénomène engendre certes une exigence accrue sur le plan interprétatif, surtout dans le contexte du travail collaboratif assez vertigineux que nécessite la signature collective, de chaque ligne de nos ouvrages et qui fait la spécificité de notre équipe. C'est toutefois ce partage plus fin et réalisé en amont qui nous semble tendre à contrebalancer le mouvement de zoom arrière qu'oblige l'effet de synthèse et dont l'impact s'accroit à chaque tranche historique ; en gros, il faut procéder à un surplomb de plus en plus périlleux pour saisir cette globalité tout en traitant du cœur, du panorama et des marges dans un même souffle. Enfin, en troisième lieu, la conservation et la capacité à rendre disponible nos données sont considérablement facilitées les outils numériques, ce qui rend possible des échanges et collaborations, notamment avec les autres équipes, les chercheurs individuels et les étudiants, à travers un partage aussi nécessaire que rentable,

tant des données que des différents états de leur interprétation.

Les trois constats qui précèdent lestent notre conviction d'avoir opéré le "virage numérique » en étant fidèles à nos principes de départ et à notre mandat scientifique. Le fait de pouvoir être attentif aux modalités de la réduction opérée sur la matière pour produire notre synthèse documente de manière révélatrice les étapes du processus. Dans le contexte d'un champ littéraire longtemps marqué par une forte hétéronomie, les soubresauts du processus, les crises qu'il révèle, les accommodements provoqués par cette adaptation au marché spécifique que constitue le champ culturel québécois, les emprunts, les décalages et autres adaptations aux réalités économiques, politiques et sociales sont peut-être les aspects les plus révélateurs de la spécificité de I'histoire littéraire et culturelle du Québec. C'est en ce sens que, de notre point de vue, notre travail s'inscrit bien davantage dans la foulée de la rupture introduite par l'école des Annales que dans le sillage de quelque révolution numérique que ce soit. Et collaborative work necessary to collectively sign each of our books, which is a trademark of our team. It appears to us that this finer, earlier selection process tends to offset the "zoom-out" movement resulting from the synthesis effect, whose impact increases with each new historical period. Roughly speaking, we need to adopt an increasingly perilous overarching perspective to get a sense of this totality and to address its heart, the wider perspective, and the margins in the same breath. The third and final aspect deserving emphasis is that digital tools have made it considerably easier to store data and make it available, which in turn makes exchanges and collaborations possible with other teams, individual researchers, and students. Sharing the data and their interpretation at various stages is both a necessary and a valuable endeavor.

The three observations made in the previous paragraph increase our confidence that in committing to the digital transition we have remained faithful to our original principles and our scientific mandate. Our attention to the modalities of the reduction of our basic materials required to produce our synthesis insightfully documents the steps in the process. In the context of a literary field that was for a long time characterized by a high degree of heteronomy, the fits and starts of the process, the crises it reveals, the arrangements made necessary by the adaptation to the specific market of Quebec's cultural field, the borrowings, discrepancies, and adjustments to economic, political, and social realities might be the most distinctive features of the specificity of Quebec's literary and cultural history. In that sense, we believe that our work is to a far greater degree an extension of the shift introduced by the Annales School than the manifestation of a digital revolution. Thanks to this approach, our study of Quebec's literary ecosystem 
c'est justement depuis cette perspective que l'intérêt d'étudier l'écosystème littéraire québécois offre des bénéfices qui dépassent largement les enjeux « locaux » pour se situer plutôt sur les plans historiographiques et épistémologiques. Les bases de données que nous avons brièvement présentées, leur conception mais également leur utilisation concrète au fil de nos analyses, nous ramènent constamment à la nécessité de compenser la réduction et les distorsions par l'élucidation des conditions de production du savoir et l'approfondissement métaréflexif, mais aussi à la mise en valeur des profits heuristiques que produit ce type de travail.

Marie-Frédérique Desbiens Université du Québec à Montréal/Université Laval - Centre de recherch interuniversitaire sur la littérature et la culture québécoises (CRILCQ)

\section{Chantal Savoie}

Université du Québec à Montréal - Centre de recherche interuniversitaire sur la littérature et la culture québécoises (CRILCQ) yields historiographical and epistemological rewards that go far beyond our local case. The databases briefly presented here, their conception as well as their practical use in the course of our analytical work constantly bring us back to the need to make up for reduction and distortions by elucidating the conditions of production of knowledge and committing to a meta-reflexive effort; but they also call us to highlight the heuristic benefits of this kind of work.

Marie-Frédérique Desbiens

Université du Québec à Montréal/Université Laval - Centre de recherche interuniversitaire sur la littérature et la culture québécoises (CRILCQ)

\section{Chantal Savoie}

Université du Québec à Montréal - Centre de recherche

interuniversitaire sur la littérature et la culture québécoises (CRILCQ) 


\section{Références bibliographiques}

Bourdieu Pierre (1992). Les Règles de l'art. Paris, Seuil.

Denis Benoît \& Marneffe (DE) Daphné (dir.) (2006). Les Réseaux littéraires. Bruxelles, Le Cri/CIEL.

DuBols Jacques (1978). L'Institution de la littérature : introduction à une sociologie. Paris/Bruxelles, Nathan/Labor.

Foucault Michel (1969). L’Archéologie du savoir. Paris, Gallimard.

HABERMAS Jürgen (1997) [1962]. L'Espace public. Archéologie de la publicité comme dimension constitutive de la société bourgeoise. Traduit de l'allemand par Marc B. de Launay. Paris, Payot.

Kalifa Dominique, Régnier Philippe, Thérenty Marie-Ève, Vaillant Alain (dir.) (2012). La Civilisation du journal. Histoire culturelle et littéraire de la presse française au XIX siècle. Paris, Nouveau Monde.

LACROIX Michel (2014). L'Invention du retour d'Europe : réseaux transatlantiques et transferts culturels. Québec, Presses de l'Université Laval.

LACROIX Michel \& SAVOIE Chantal, avec la collaboration d'Olivier LAPOINTE (2015). " Des crises continuelles aux trajectoires continues : les transformations de la vie littéraire au Québec, 1895-1948 ». Sociologies et sociétés, 47(2) : 189-210.

\section{References}

Bourdieu Pierre (1996). The Rules of Art: Genesis and Structure of the Literary Field. English translation by Susan Emanuel. Palo Alto, Stanford University Press.

Denis Benoît \& Marneffe (DE) Daphné (eds.) (2006). Les Réseaux littéraires. Bruxelles, Le Cri/CIEL.

Dubols Jacques (1978). L'Institution de la littérature: introduction à une sociologie. Paris/Bruxelles, Nathan/Labor.

FoucAult Michel (2002). The Archaeology of Knowledge. Translated into English by A.M. Sheridan Smith. London/New York, Routledge.

Habermas Jürgen (1989) [1962]. The Structural Transformation of the Public Sphere: An Inquiry into a Category of Bourgeois Society. Translated into English by Thomas Burger and Frederick Lawrence. Cambridge, The MIT Press.

Kalifa Dominique, RéGnier Philippe, Thérenty Marie-Ève, Valllant Alain (eds.) (2012). La Civilisation du journal. Histoire culturelle et littéraire de la presse française au XIX $X^{e}$ siècle. Paris, Nouveau Monde.

LACROIX Michel (2014). L'Invention du retour d'Europe: réseaux transatlantiques et transferts culturels. Québec, Presses de l'Université Laval.

LACROIX Michel \& SAVOIE Chantal, avec la collaboration d'Olivier LAPOINTE (2015). "Des crises continuelles aux trajectoires continues: les transformations de la vie littéraire au Québec, 1895-1948." Sociologies et sociétés, 47(2): 189-210. 
MORETTI Franco (2008). Graphes, cartes et arbres. Modèles abstraits pour une autre histoire de la littérature. Traduit de l'anglais par Étienne Dobenesque. Paris, Les Prairies ordinaires.

Robert Lucie (2012). " La vie culturelle et son histoire. Quelques réflexions sur la notion de "vie" ». Globe, $15: 231-242$.

SAINT-JACQUES Denis \& Lemire Maurice (dir.) (2005). La Vie littéraire au Québec, t. 5 : «1895-1918. Sois fidèle à ta Laurentie ». Québec, Presses de l'Université Laval.

SaINT-JACques Denis \& Robert Lucie (dir.) (2010). La Vie littéraire au Québec, t. 6 : « 1919-1933. Le nationaliste, l'individualiste et le marchand ». Québec, Presses de l'Université Laval.

SAPIRO Gisèle (2008). " Mesure du littéraire. Approches sociologiques et historiques », Histoire \& Mesure, 23(2) : 35-68.

THÉRENTY Marie-Ève (2007). La Littérature au quotidien : poétiques journalistiques au xix siècle. Paris, Seuil.

THÉRENTY Marie-Ève (2012). « Le renouvellement de l'histoire littéraire ». In KUPERTY-TsUR Nadine (dir.). La Critique au tournant du siècle. Mélanges offerts à Ruth Amossy. Louvain, Peeters : 117-135.

VAN SCHendel Michel (1979). «Appareil et Institution (littéraire) 》. Recherches et Théories, $19: 1-14$.
MoRETTI Franco (2005). Graphs, Maps, Trees: Abstract Models for Literary History. New York, Verso.

Robert Lucie (2012). "La vie culturelle et son histoire. Quelques réflexions sur la notion de "vie."' Globe, 15: 231-242.

SAINT-JACQUES Denis \& LemIRE Maurice (eds.) (2005). La Vie littéraire au Québec, t. 5:"1895-1918. Sois fidèle à ta Laurentie." Québec, Presses de l'Université Laval.

SAINT-JACQUes Denis \& Robert Lucie (eds.) (2010). La Vie littéraire au Québec, t. 6: "1919-1933. Le nationaliste, l'individualiste et le marchand." Québec, Presses de l'Université Laval.

SAPIRO Gisèle (2008). "Mesure du littéraire. Approches sociologiques et historiques." Histoire \& Mesure, 23(2): 35-68.

THÉRENTY Marie-Ève (2007). La Littérature au quotidien: poétiques journalistiques au XIXe siècle. Paris, Seuil.

THÉRENTY Marie-Ėve (2012). "Le renouvellement de l'histoire littéraire." In KUPERTY-Tsur Nadine (ed.). La Critique au tournant du siècle. Mélanges offerts à Ruth Amossy. Louvain, Peeters: 117-135.

VAN Schendel Michel (1979). "Appareil et Institution (littéraire)." Recherches et Théories, 19: 1-14. 